\title{
Detention in Canada: Are We on the Slippery Slope?
}

\author{
Catherine Gauvreau and Glynis Williams
}

\begin{abstract}
Canada's detention policies and practices are far less draconian than those of our neighbours. There are nevertheless concerns about the commitment to detain more people as a measure of security and deterrence, in part as the response to September 11. This article describes the situation of detention in Canada, making reference to new legislation passed in November 2001.
\end{abstract}

\section{Résumé}

Les politiques et les pratiques de détention du Canada sont bien moins draconiennes que celles de nos voisins. Malgré tout, des inquiétudes ont été exprimées sur l'engagement à détenir plus de gens par mesure de sécurité et de dissuasion - partiellement en réaction au 11 septembre. Cet article décrit la situation de la détention au Canada, tout en se référant à la nouvelle législation adoptée en novembre 2001.

C anada's problem is that we often look good by comparison. This statement definitely applies to Canhorrendous stories of injustice and inhumane treatment of asylum seekers in Australia, France, the United States, and many other countries have lowered the standard to such a place that we risk being numbed to the fundamental human rights that are eroding, even in Canada.

The following brief comments are the reflections of a small non-governmental organization, Action Réfugiés Montréal, which visits regularly the detention centre located outside Montreal, Quebec. One evening each week, the detention worker, accompanied by several volunteers and law students, can be found providing legal information and emotional support to those who are in detention. Visits are restricted to the common lounge areas and detainees can decide whether they wish to avail themselves of this service or not.

Asylum seekers who are just entering the country as well as those who have been refused and are subject to removal are among the population detained. Statistics from Citizenship and Immigration Canada (CIC) indicate that at any one time there are an average of 455 persons detained under the Immigration Act across the country. The average number of minors detained for immigration reasons at any one time, both accompanied and unaccompanied, is eleven across Canada. There are no statistics indicating how many persons detained are refugee claimants. The three main grounds for detention are flight risk, danger to the public (criminality and security), and identity.

In addition to providing information, Action Réfugiés workers attempt to find lawyers to represent people at their detention reviews, which are regularly scheduled hearings to determine if detention is to be continued or the person released. On occasion long distance phone cards are provided so that detainees can contact families and obtain documents to establish their identity or support their refugee claim. Another important aspect of the work is monitoring the conditions in detention: who is being detained and for what reasons. Anecdotal evidence suggests that persons with apparent mental health problems and communication difficulties are overrepresented in the population. Finally, we assist people to make arrangements to leave in dignity and with the resources needed to survive upon return to their country of origin.

\section{Background}

New legislation entitled The Immigration and Refugee Protection Act (IRPA) passed into law November 1, 2001. Im- 
plicit in the legislation is the motif of the immigrant- as-security-threat. ${ }^{1}$ In the name of security, among other measures the new Act expands the use of detention. The grounds for detention remain the same but the new bill broadens the provisions whereby people can be detained at the port of entry and throughout the determination process. This is significant for refugee claimants. For example, a person can be detained in order to continue an interview; in other words, for administrative convenience. More disturbing is the identity document provision which directly affects refugee claimants who are sometimes forced to flee without identification, because it is their identity which puts them at risk. Once someone is detained for identity reasons, the bill suggests that they may be detained for long periods. ${ }^{2}$ Historically, Canada has not detained large numbers of refugee claimants at ports of entry. It appears as though a shift in policy is emerging, with detaining of people in groups, such as Chinese claimants who arrived in significant numbers by boat in 1999 .

Although the legislation was in the works long before September 11, 2001, there is no doubt that anxiety regarding security has influenced the public debate. Immigration Minister Denis Coderre has indicated that measures focusing on deterrence and detention are part of the safety and security strategies being employed. ${ }^{3}$ It is in this context that the following comments are made.

\section{Current Concerns}

Immigration detainees are held in one of three centres run by CIC or in jails. In regions where CIC has no facility, people are transferred into the prison system, alongside the criminal population. To be detained is to be imprisoned. Surveillance cameras, entry searches with metal detectors, chain-link perimeter fences topped by barbed wire, handcuffing during transfers, and restricted access to the outside leave no doubt that the detention centres are prisons. In smaller cities, there may not be any NGOs working with refugees and the UN High Commission for Refugees (UNHCR) is not able to respond even if contacted. An additional complication is that CIC says it is unable to provide data indicating where people are held and if they are claiming refugee status. Lengthy detention can result when people have no access to advocates and legal counsel.

The detention of children, whether separated or with family, is a disturbing phenomenon. The IRPA states that the detention of minors should only occur as a last resort, and that decision makers must consider the best interests of the child. There is concern expressed by both NGOs and the Parliamentary Standing Committee on Citizenship and Immigration that the regulations do not adequately incorporate this principle. They leave the
Detention when unable to remove someone is inhumane. A. is stateless. In spite of having no country to which he can be removed he endured a long period in detention. A victim of the breakup of the former Soviet Union, he is denied residency in Estonia where he grew up because they consider him Russian. Russia refused him entry because he has never lived there. Ironically, had he not met Action Réfugiés staff while in detention, he might never have been in contact with UNHCR who determine statelessness. Sadly, CIC lost the opportunity to include stateless persons in the category of persons needing protection in the new law.

A thirteen-year-old Congolese girl is being held with her father in the Laval detention centre. She has been detained for three weeks now because the authorities are not satisfied with the lack of original documents. Symptoms of depression are appearing. When we visited her on the eve of Good Friday, her Bible was open to Psalm 142 which she said she liked to sing. The passage read: "I call to my Lord for help. I tell him all my troubles. When I am ready to give up, He knows what I should do." One wonders who is determining the best interests of this child.

impression that if detention facilities are adequate, minors can be detained.

There is fear that children brought by people smugglers will be detained for reasons of protection, a view that is opposed by advocates, who favour other options such as safe houses. Children should not be detained for lack of identity documents alone, which is the current practice. ${ }^{4}$

Since September 11, there have been calls for greater co-operation between the U.S. and Canada, including the exchange of information and a harmonization of immigration policies. Given the power imbalance between the two countries, harmonization would inevitably result in Canada adopting U.S. practice. In 1996, the U.S. adopted laws which resulted in massive increases in immigration detention. These measures did nothing to protect the country 
from the September 11 attacks. ${ }^{5}$ In other words, there is no automatic link between detention and security. Sophisticated criminals will find ways to bypass detection, often using excellent documents to enter the country, a fact demonstrated by the September 11 perpetrators. Large-scale detention in the U.S. has not addressed security concerns and imposes serious hardship on refugees seeking protection.

\section{Hopeful Initiatives}

After many months of negotiation, Action Réfugiés has recently signed an agreement with CIC which details access rights and practices. In the preamble, several assertions contained in early drafts regarding the principles implicit in relevant human rights treaties were deleted on the basis that they were self-evident, as Canada has signed these conventions. While this was a disappointment, we are pleased to have our work with detainees officially recognized.

Colleagues in other countries have often commented on the effectiveness of the refugee advocacy community in Canada, with special acknowledgement being given to the Canadian Council for Refugees (CCR). In the course of recent consultations with CCR members and Immigration Department officials, we were encouraged by the commitment to develop an external complaints mechanism and to establish Citizens Advisory Committees for Immigration detention centres. Both these initiatives would be important monitoring mechanisms, something that is seriously lacking in the current system. A final positive initiative is an agreement that CIC has signed with the Canadian Red Cross to do monitoring. ${ }^{6}$

\section{Conclusion}

Comparisons can ignore the ideals against which we must ultimately be judged. Detention deprives individuals of a most basic human right, liberty, and must therefore be considered an extraordinary measure. With rare exceptions, detainees have not been accused of any crime, and yet they are locked up behind barbed wire. For those who have fled repressive regimes and hope to find protection here, the trauma of detention can be devastating.

Detention has been described as a grey zone in refugee work, not well understood and, consequently, seriously underfunded. And yet, it is a snapshot of how well we are defending the human rights of all people. Lest we find ourselves in the same situation as too many other countries, it is time we paid more attention to the realities of detention in Canada.

\section{Notes}

1. Audrey Macklin, "Borderline Security," in The Security of Freedom, R. Daniels et al. (Toronto: University of Toronto Press, 2001), 383.

2. For more analysis on this and other aspects of Bill C-11, consult the Canadian Council for Refugees website, online: $<$ www.web.net/ $\sim \mathrm{ccr}>$.

3. CIC News Release, February 26, 2002, Backgrounder C.

4. Action Réfugiés made representation on C-11 focusing on these issues in detention and on the issue of statelessness. The comments are available upon request.

5. Post-September 11: Questions about Refugees and Refugee Policies, Canadian Council for Refugees.

6. The Canadian Red Cross will monitor detention conditions to ensure that Canada conforms to International conventions and norms. Their reports are given to CIC and are not made public. This initiative was at the request of CIC.

Catherine Gauvreau works part-time as the Detention Worker for Action Réfugiés Montréal, Canada.

Glynis Williams is the Director of Action Réfugiés Montréal, Canada. 